\title{
Radiation Environment of Mangrove Pneumatophores in Brackish Water
}

\author{
Takashi Hirano, Ichiro Aiga, Nobutaka Monji, Ken Hamotani, Vipak Jintana, ${ }^{*}$ \\ Toshio ISHIKAWA** and Kazutoshi YABUKI \\ College of Agriculture, Osaka Prefecture University, Sakai 593, Japan \\ * Forest Research Office, Royal Forest Department, Bangkok 10900, Thailand \\ ** Image \& Remote Sensing Research Center, Chiba University, Chiba 263, Japan
}

(Received September 25, 1995)

\begin{abstract}
The pneumatophores of Avicennia and Sonneratia species photosynthesize and the photosynthetically generated $\mathrm{O}_{2}$ is used for the respiration in the roots in subsoil. To understand the radiation environment of the pneumatophores, we measured solar radiation on the vertical surface $\left(R_{\mathrm{v}}\right)$ in the water with dye films. The $R_{\mathrm{v}}$ averaged over the daytime at a depth of $30 \mathrm{~cm}$ was similar to the light compensation points in the pneumatophores. From this result, it can be supposed that the photosynthesis nearly compensated the respiration at a depth of $30 \mathrm{~cm}$ and supplied $\mathrm{O}_{2}$ to the roots in subsoil at shallower places, even when the pneumatophores were submerged in the daytime.
\end{abstract}

\section{INTRODUCTION}

Some species of the mangrove growing in muddy tidal flats have pneumatophores with a distinct green layer including chlorophyll just beneath the epidermis. These pneumatophores, shaped like a rocket, are standing on the mud and submerged according to the tide.

Yabuki et al. (1990 a, b, 1991) found that the green layers in pneumatophores of Avicennia and Sonneratia species photosynthesize and that the photosynthetically generated $\mathrm{O}_{2}$ is used for the respiration in the roots in subsoil. This photosynthesis has the same features as those of shaded leaves, which have low light compensation points (Yabuki et al., 1990 a) and high activity at low light intensities (Aiga et al., 1995).

In order to understand the radiation environment of the pneumatophores as the dominant factor of photosynthesis, we measured the solar radiation on both the vertical and horizontal surfaces in the brackish water by using the dye film developed by Yoshimura et al. (1990) for the estimation of integrated total solar radiation. From the cylindrical form of the pneumatophores, the photosynthesis should be estimated with the solar radiation on the vertical surface $\left(R_{\mathrm{v}}\right)$, not with that on the horizontal one $\left(R_{\mathrm{h}}\right)$.

\section{MATERIALS AND METHODS}

The experiment was conducted at a creek $\left(8^{\circ} 20^{\prime} \mathrm{N}, 98^{\circ} 27^{\prime} \mathrm{E}\right)$ in a mangrove forest in Phangnga Bay, southern Thailand, for $48 \mathrm{~h}$ from $14: 00$ on Apr. 9 to $14: 00$ on Apr. 11, 1995. The creek was about $10 \mathrm{~m}$ in width and ran to the east at high tide and to the west at low tide. At the center of the creek, a square shaped styrofoam float, weighted to keep its draft constant, was attached to a fixed pole (Fig. 1). On the surfaces of the float and its arm projecting to the south, integrated total $R_{\mathrm{v}}\left(\mathrm{N}, \mathrm{E}, \mathrm{S}\right.$ and W) and $R_{\mathrm{h}}$ were measured with dye films $(12 \times 35 \mathrm{~mm})$ 


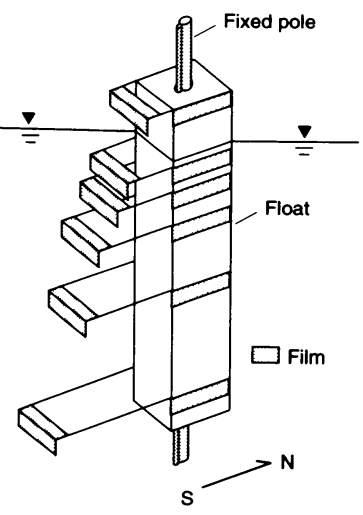

Fig. 1 Location of the dye films attached to the float.

above the water and at depths of $1,5,10,15$, and $30 \mathrm{~cm}$ in the water.

The dye film is a simple instrument for measurement of integrated total solar radiation by using the light fading of its color. This film is a photographic triacetylcellulose film base impregnated with an azo dye (Oil Red O). Integrated solar radiation was calculated from the following equation (Yoshimura et al., 1990),

$$
k R=-\ln \frac{D}{D_{0}}
$$

where $k$ is the rate constant, $R$ the total amount of incident radiation, and $D_{0}$ and $D$ the absorbance of the film before and after exposure to sunlight, respectively. Here, the value of $k$ was determined from Eq. (1) with the $D$ and $D_{0}$ on the horizontal surface above the water and integrated global radiation as $R$. $D$ and $D_{0}$ were measured at the peak absorption wavelength $(520 \mathrm{~nm})$ by using a spectrophotometer

(Jasco, Ubest-50) with an integration sphere (Jasco, TIS-341). Global radiation was measured with a pyranometer (Eko, MS-100) at the top of the $15 \mathrm{~m}$ high tower, about $5 \mathrm{~m}$ above the mangrove canopy, located about $50 \mathrm{~m}$ north from the experimental point.

\section{RESULTS AND DISCUSSION}

The result is shown in Table 1. The hourly average of global radiation is shown in Fig. 2. There was clear weather during most of the experimental period except for the late afternoon on Apr. 9. The films attached to the float were kept out of the shade of the surrounding trees throughout the experimental period. The solar altitude at culmination was $89^{\circ}$. The brackish water in the creek was always muddy because of fine suspended soil particles, so that the films at a depth of $30 \mathrm{~cm}$ were not visible.

The integrated $R_{\mathrm{h}}$ in the water decreased to half of that above the water (global radiation), at a depth of $5 \mathrm{~cm}$, and to only $1 / 20$ at $30 \mathrm{~cm}$. From the data at $30 \mathrm{~cm}$, Lambert-Beer's law gave an extinction coefficient of $10 \mathrm{~m}^{-1}$.

Table 1 Integrated solar radiation $\left(\mathrm{MJ} \mathrm{m}^{-2}\right)$ for $48 \mathrm{~h}$ (Apr. 9 to Apr. 11, 1995).

\begin{tabular}{cccccccc}
\hline \multirow{2}{*}{ Direction } & \multirow{2}{*}{$\begin{array}{c}\text { Above } \\
\text { water }\end{array}$} & \multicolumn{5}{c}{ Depth of water (cm) } \\
\cline { 4 - 7 } & & 1 & 5 & 10 & 15 & 30 \\
\hline \multirow{2}{*}{ Horizontal } & & $47.7 \pm 0.7^{*}$ & $40.5 \pm 0.9$ & $23.9 \pm 0.8$ & $15.3 \pm 0.4$ & $7.6 \pm 0.6$ & $2.4 \pm 0.2$ \\
& & $(100)^{* *}$ & $(85)$ & $(50)$ & $(32)$ & $(16)$ & $(5)$ \\
Vertical & $\mathrm{N}$ & $2.9 \pm 0.2$ & $2.8 \pm 0.3$ & $2.8 \pm 0.3$ & $2.4 \pm 0.2$ & $2.3 \pm 0.2$ & $1.9 \pm 0.2$ \\
& & $(6)$ & $(6)$ & $(6)$ & $(5)$ & $(5)$ & $(4)$ \\
& $\mathrm{E}$ & $14.8 \pm 0.4$ & $7.2 \pm 0.4$ & $3.4 \pm 0.3$ & $2.9 \pm 0.2$ & $2.4 \pm 0.2$ & $1.5 \pm 0.1$ \\
& & $(31)$ & $(15)$ & $(7)$ & $(6)$ & $(5)$ & $(3)$ \\
& $\mathrm{S}$ & $6.7 \pm 0.3$ & $4.3 \pm 0.3$ & $3.3 \pm 0.3$ & $2.4 \pm 0.2$ & $1.9 \pm 0.2$ & $1.4 \pm 0.1$ \\
& & $(14)$ & $(9)$ & $(7)$ & $(5)$ & $(4)$ & $(3)$ \\
& $\mathrm{W}$ & $12.9 \pm 0.4$ & $6.2 \pm 0.4$ & $3.8 \pm 0.4$ & $2.9 \pm 0.3$ & $2.3 \pm 0.2$ & $1.9 \pm 0.2$ \\
& & $(27)$ & $(13)$ & $(8)$ & $(6)$ & $(5)$ & $(4)$ \\
\hline
\end{tabular}

* Mean $\pm \mathrm{SD}(N=4$ for the horizontal surface and $N=3$ for vertical surface).

** Percentage of the mean at the horizontal surface above water. 


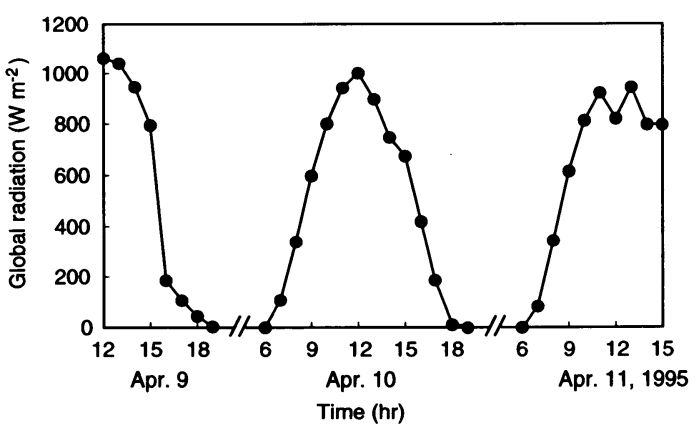

Fig. 2 The change in hourly averaged global radiation measured with a pyranometer.
The integrated $R_{\mathrm{v}}$ above the water was about $30 \%$ of global radiation on the east and west surfaces, $14 \%$ on the south and only $6 \%$ on the north. Since the $R_{\mathrm{v}}$ became higher when solar altitude was low, such as in the early morning and evening, the $R_{\mathrm{v}}$ on the east and west surfaces was higher than that on the south. On the north surface, the $R_{\mathrm{v}}$ consisted of only diffused and reflected radiation. In the water, the $R_{\mathrm{v}}$ on both the east and west surfaces decreased as the depth increased although that on the north was nearly

independent of the depth. At a depth of $1 \mathrm{~cm}$, the $R_{\mathrm{v}}$ on the east and west surfaces was 13$15 \%$ of global radiation, and higher than that on the south and north. However, at depths of over $5 \mathrm{~cm}$, the $R_{\mathrm{v}}$ on all 4 directions were similar. Moreover the difference between the $R_{\mathrm{v}}$ and $R_{\mathrm{h}}$ was very small at $30 \mathrm{~cm}$. These showed that almost all sunbeams became diffused at depths of over $5 \mathrm{~cm}$ in this muddy water. Although the diurnal changes in the $R_{\mathrm{v}}$ on the 4 directions were probably different even in the water, it was inferred that the amount of solar radiation incident upon the whole surface area around the pneumatophore, at a depth of 30 $\mathrm{cm}$, changed little over the daytime except for the early morning and evening. At 5, 10,15, and $30 \mathrm{~cm}$, averages of the $R_{\mathrm{v}}$ for the 4 directions were $3.33,2.65,2.23$, and $1.68 \mathrm{MJ} \mathrm{m}^{-2}$, respectively. From these averages and the total day length $(24 \mathrm{~h})$ during the experimental period $(48 \mathrm{~h})$, the $R_{\mathrm{v}}$ averaged over the daytime of $39,31,26$, and $19 \mathrm{~W} \mathrm{~m}^{-2}$ was determined at depths of 5 , 10,15 , and $30 \mathrm{~cm}$, respectively.

Yabuki et al. (1990a) reported that the light compensation points of photosynthesis in pneumatophores of Avicennia marina and Sonneratia alba range from 0.02 to $0.03 \mathrm{cal} \mathrm{cm}^{-2}$ $\min ^{-1}$ ( $=14$ to $21 \mathrm{~W} \mathrm{~m}^{-2}$ ). These values are similar to the $R_{\mathrm{v}}$ averaged over the daytime at a depth of $30 \mathrm{~cm}$. In their study, the compensation points were determined from the relation between light intensity per unit horizontal area and photosynthetic rates measured with a chamber in which pneumatophores were laid horizontally, under the condition of downward lighting. In the measurement, the lower surfaces of the laid pneumatophores were probably shaded. Therefore, if the light intensity averaged over the surface area was used as in this study, the light compensation points would become lower. In conclusion, it can be supposed that the photosynthesis in the pneumatophores nearly compensated the respiration at a depth of $30 \mathrm{~cm}$, and could supply $\mathrm{O}_{2}$ to the roots in subsoil at shallower places, even when the pneumatophores were submerged in the daytime. It is needless to say that this conclusion was derived from results under limited environmental conditions and further experiments are needed under other conditions.

We acknowledge Dr. Sanga Sabasri and Ms. Prapasri Thanasukarn, The National Research Council of Thailand, Dr. Jitt Kongsanchai, Royal Forest Department, and Dr. Makoto Kiyota, Osaka Prefecture University, for their constant support throughout the experiment, and Mr. Somsak Piriyayotha and his staff in the Royal Forest Department, for helping us in the field work. This research was supported by a grant from Nippon Life Insurance Foundation. 


\section{REFERENCES}

Aiga, I., Nakano, Y., Ohki, S., Kitaya, Y., Yabuki, K. 1995. Photosynthetic $\mathrm{CO}_{2}$ fixation in pneumatophores of gray mangrove, Avicennia marina. Environ. Control in Biol. 33 : 97-101.

Yabuki, K., Kitaya, Y., Sugi, J. 1990a. Studies on the function of mangrove pneumatophores (1). Environ. Control in Biol. 28 : 95-98 (in Japanese with English summary).

Yabuki, K., Kitaya, Y., Sugi, J. 1990b. Studies on the function of mangrove pneumatophores (2). Environ. Control in Biol. 28 : 99-102 (in Japanese with English summary).

Yabuki, K., Kitaya, Y., Sugi, J. 1991. The functional adaptation of mangrove pneumatophores to the tide level. Bull. Soc. Sea Water Sci. 45 : 126-129 (in Japanese).

Yoshimura, T., Ishikawa, T., Komiyama, K. 1990. Simple measurement of integrated solar radiation. Int. J. Sol. Energy 9 : 193-204.

\section{〈和文抄録〉}

\section{マングローブ直立気根の水中光環境}

平野高司・相賀一郎・文字信费・觛谷 意・ウィパックチンタナ* 石川敏雄**・矢吹芸婹

大阪府立大学農学部, *夕イ王立森林庁, ${ }^{* *}$ 千葉大学映像隔測研究センター

潮間帯に生息するマングローブの Avicennia 属や Sonneratia 属の直立気根には，表皮の直下に 葉緑素を含む層状の組織が存在する.この組織では光合成が行われ, 生成される酸素が地中根の呼 吸に利用されることが知られている. 本研究では, 直立気根の水没時における光合成を評価するた めに, 色素の光退色を利用した簡易積算日射フィルムを用いて, 水中での水平面および鉛直面にお ける積算日射量をタイのマングローブ林において測定した。その結果, かなり濁った水中において も, $30 \mathrm{~cm}$ 程度までの水深では, 鉛直面での日平均日射量は光合成の光補償点以上であった.この ことは, 水没時においても直立気根が光合成によって地中根へ酸素を供給することを示唆してい る. 